\title{
Relações solo-paisagem no Quadrilátero Ferrífero em Minas Gerais
}

\author{
Amaury de Carvalho Filho(1), Nilton Curi(2) e Edgar Shinzato(3) \\ (1)Embrapa Solos, Rua Jardim Botânico o 1.024, CEP 22460-000 Rio de Janeiro, RJ. E-mail: amaury@cnps.embrapa.br (2)Universidade \\ Federal de Lavras, Departamento de Ciência do Solo, CEP 37200-000 Lavras, MG. E-mail: niltcuri@dcs.ufla.br ${ }^{(3)}$ Companhia de Pesquisa de \\ Recursos Minerais, Avenida Pasteur № 404, Urca, CEP 22290-240 Rio de Janeiro, RJ. E-mail: shinzato@rj.cprm.gov.br
}

Resumo - O objetivo deste trabalho foi caracterizar os solos de uma área representativa do Quadrilátro Ferrífero, em Minas Gerais, e avaliar suas relações com os principais componentes do meio natural. Sete unidades de paisagem (pedoambientes) distintas foram identificadas - Depressão do Paraopeba, Serras Itabiríticas, Platô da Moeda, Vale do Rio das Velhas, Gandarela, Vale do Conceição e Serra do Caraça -, cujos aspectos relacionados a solos em suas interrelações com os componentes do meio natural foram descritos. Sob a influência de grande variabilidade litólógica, em conexão com um longo período de evolução geomorfológica, a região é marcada por acentuados contrastes topográficos. Há domínio de solos pouco evoluídos (Cambissolos e Neossolos Litólicos), de baixa fertilidade natural, não obstante a acentuada diferenciação da vegetação nativa, representada por formações campestres lado a lado à floresta. Em algumas áreas é expressiva a ocorrência de afloramentos rochosos. É marcante a influência do material de origem nas características dos solos, com destaque para o conjunto de solos relacionados a rochas ferríferas, distinguidos pelos teores de óxidos de ferro muito elevados e intensa cor vermelha. A presença de concreções ferruginosas é também muito comum nesses solos. A ocorrência de Latossolos Vermelhos perférricos, desprovidos de pedregosidade, está associada principalmente a formações pedimentares nas adjacências das Serras Itabiríticas.

Termos para indexação: rochas ferríferas, solos concrecionários, solos perférricos, solos tropicais.

\section{Soil-landscape relationships at the Quadrilátero Ferrífero in the state of Minas Gerais, Brazil}

\begin{abstract}
The objective of this work was characterize the soils of a typical area of the Quadrilátero Ferrífero, Minas Gerais, Brazil, and to evaluate the relationships between these soils and the main components of the natural ambience. Seven distinct landscape units were identified - Depressão do Paraopeba, Serras Itabiríticas, Platô da Moeda, Vale do Rio das Velhas, Gandarela, Vale do Conceição, Serra do Caraça - whose aspects related to soils and their relationships with the components of the natural ambience were described. Under the influence of a great lithologic variability, in connection with a large period of geomorphologic evolution, the region is marked by strong topographic contrasts. There is a dominance of young soils (Cambisols and Litholic Neosols), showing low natural fertility, despite the marked differentiation of native vegetation, represented by tropical grassland formations side by side to the forest. In some areas, rocky outcrops are outstanding. The influence of the parent material on soil characteristics is remarkable, especially on the soil groups related to iron rocks, which are discernible by their very high iron oxide contents and their intense red color. The presence of ferruginous concretions is also very common in this soils. The occurrence of perferric soils (Oxisols), without coarse fragments, is associated to the pediment formation at the Serras Itabiriticas vicinity.
\end{abstract}

Index terms: ferriferous rocks, concretionary soils, perferric soils, tropical soils.

\section{Introdução}

O Quadrilátero Ferrífero, que abrange uma área aproximada de $7.000 \mathrm{~km}^{2}$ na porção centro-sul do Estado de Minas Gerais, destaca-se no cenário nacional tanto no plano econômico quanto no histórico-cultural, em relação direta com sua riqueza em recursos minerais. Constitui um dos segmentos mais antigos da paisagem brasileira, com raízes em tempos juro-cretáceos, quando, unidas, as terras da América do Sul, África, Oceania e Antártida formavam o supercontinente Gondwana.

Apesar da diversidade das condições ambientais, propícias ao desenvolvimento de investigações nos mais diversos ramos das ciências naturais, a abundância em recursos minerais do substrato geológico e a enorme variabilidade litológica têm conduzido a uma concentração de estudos sobre esses temas. Assim, 
poucas são as pesquisas dedicadas aos solos, em geral direcionadas a assuntos específicos ou restritas a pequenos trechos da paisagem regional (Curi \& Franzmeier, 1987; Reunião de Classificação, Correlação de Solos e Interpretação de Aptidão Agrícola, 1988; Ker \& Schaefer, 1995; Costa, 2003; Figueiredo et al., 2006), que é contemplada apenas por levantamentos pedológicos de caráter muito geral, referentes ao Projeto RadamBrasil, em escala 1:1.000.000, que cobre toda a área, e ao levantamento de reconhecimento, em escala 1:500.000, realizado pela Fundação Centro Tecnológico de Minas Gerais, para a parte pertencente à bacia de captação do rio São Francisco. Apenas recentemente uma porção expressiva da região foi palco de um levantamento de solos mais detalhado, na escala 1:50.000 (Shinzato \& Carvalho Filho, 2005).

O conhecimento desse importante recurso natural, seja no que concerne à sua distribuição espacial, seja no interrelacionamento com os componentes bióticos e abióticos do meio, e mesmo no que tange às suas características intrínsecas, é portanto ainda incipiente.

O objetivo deste trabalho foi realizar uma caracterização abrangente dos solos e avaliar suas relações com os principais componentes do meio natural, em uma área representativa do Quadrilátero Ferrífero, com a finalidade de contribuir tanto para o conhecimento das características e da distribuição dos solos na paisagem, quanto para a distinção e reconhecimento de ambientes na região.

\section{Material e Métodos}

O trabalho foi desenvolvido em área representativa do Quadrilátero Ferrífero, que abrange tratos expressivos de seu território e de quase todas as províncias geomorfológicas que o compõem, referente à Área de Proteção Ambiental da Região Metropolitana de Belo Horizonte (APA Sul RMBH), com extensão de $1.625,32 \mathrm{~km}^{2}$, situada entre $19^{\circ} 55^{\prime}$ e $20^{\circ} 15^{\prime} \mathrm{S}$ e $42^{\circ} 55^{\prime}$ e $44^{\circ} 15^{\prime} \mathrm{W}$ (Figura 1). Tendo-se como base o levantamento pedológico de reconhecimento de alta intensidade, realizado em escala 1:50.000, pela Companhia de Pesquisa de Recursos Minerais, em parceria com a Embrapa Solos (Shinzato \& Carvalho Filho, 2005), a área em estudo foi percorrida de forma abrangente, para identificar as relações entre os solos e os demais componentes do meio natural que caracterizam os grandes ambientes regionais.
Em complementação à amostragem do mapeamento citado, foram realizadas descrições e coletas de solos, conforme os preceitos de Santos et al. (2005), cujos materiais foram submetidos a análises físicas e químicas, de acordo com Claessen (1997). Na terra fina seca ao ar (TFSA), obtida após separação e quantificação volumétrica de calhaus e cascalhos, foram determinados: composição granulométrica (areia grossa, areia fina, silte e argila), argila dispersa em água, $\mathrm{pH}$ em água e em $\mathrm{KCl} 1 \mathrm{~mol} \mathrm{~L}^{-1}$, cátions trocáveis $\left(\mathrm{Ca}^{2+}, \mathrm{Mg}^{2+}, \mathrm{K}^{+}, \mathrm{Na}^{+}\right), \mathrm{Al}^{3+}$ e acidez trocável $\left(\mathrm{Al}^{3+}+\mathrm{H}^{+}\right)$, carbono orgânico e, para horizontes selecionados, teor de óxidos $\left(\mathrm{SiO}_{2}, \mathrm{Al}_{2} \mathrm{O}_{3}, \mathrm{Fe}_{2} \mathrm{O}_{3}, \mathrm{TiO}_{2}, \mathrm{P}_{2} \mathrm{O}_{5}\right.$ e $\left.\mathrm{MnO}\right)$ pelo ataque sulfúrico. Foram incluídos também os perfis III RCC-1 MG (Reunião de Classificação, Correlação de Solos e Interpretação de Aptidão Agrícola, 1988) e XXV CBCS-5 (Ker \& Schaefer, 1995), num total de 34 locais de amostragem (Figura 1 B). Os solos foram classificados de acordo com o atual Sistema Brasileiro de Classificação de Solos (Santos et al., 2006).

Com base nas observações de campo e características analíticas dos solos amostrados, e com apoio dos mapas pedológico, geológico e geomorfológico da área, foi realizada a interpretação de fotografias aéreas, em escala 1:30.000, em montagem estereoscópica, e a de imagens recentes por satélite, em escala 1:50.000, canais 3, 4 e 5, e foram delimitados os distintos pedoambientes que caracterizam a área em estudo, cujos limites e características diferenciais foram reavaliados em uma etapa posterior de verificação de campo.

\section{Resultados e Discussão}

Os limites do Quadrilátero Ferrífero são quase sempre marcados por bordas íngremes, relacionadas a serras alinhadas que assumem um arranjo aproximadamente quadrangular, grande parte delas com rochas itabiríticas da Formação Cauê, Grupo Itabira e Supergrupo Minas, que constituem a linha de cumeadas, representadas pelo detalhe em preto na Figura $1 \mathrm{~A}$. A região constitui um divisor de águas das Bacias do Rio São Francisco, que drena para o norte com seu afluente, o Rio das Velhas, que corta toda a parte central do Quadrilátero como principal eixo da drenagem, e a do Rio Doce, a leste. Sua paisagem alpestre encontra-se na confluência entre Floresta Atlântica e Cerrado, cujos elementos intercalam-se na paisagem em padrão intrincado. Assim, sob condições climáticas, marcadas por temperaturas amenas e índices 

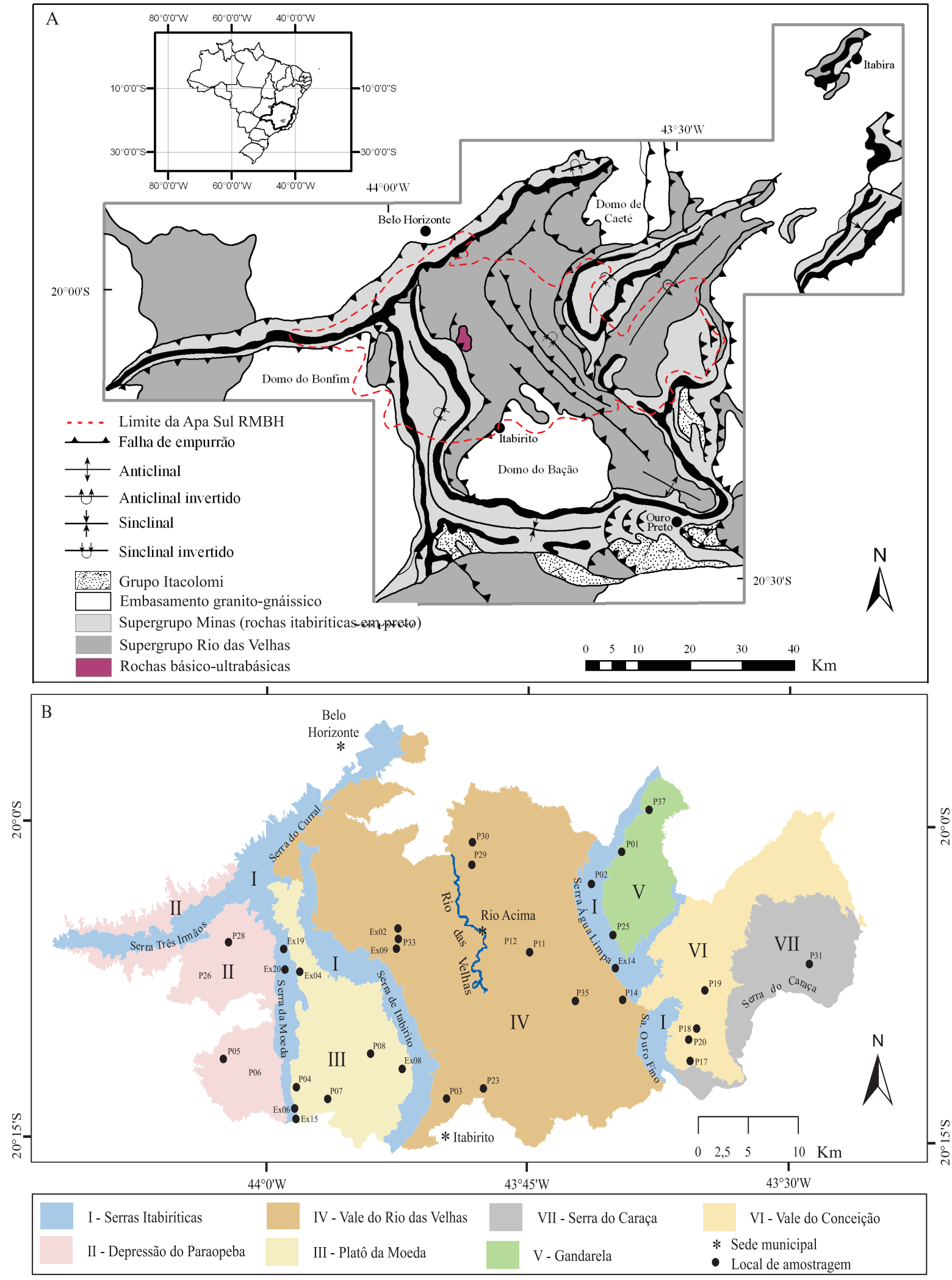

Figura 1. A, mapa de localização do Quadrilátero Ferrífero, com os principais conjuntos litológicos e feições estruturais, adaptado de Dorr II (1969) e Chemale Junior et al. (1991), e delimitação da área de estudo (APA Sul RMBH); B, distribuição geográfica dos pedoambientes identificados na APA Sul RMBH. 
pluviométricos de moderados a altos, e sob a influência da posição na paisagem e das características diferenciais dos solos, formações florestais e vegetação campestre ou áreas de cerrado convivem lado a lado. É marcante na região a interferência da litologia e das condições estruturais sobre a evolução do relevo (Varajão et al., 2009) e sobre a distribuição e características dos solos, cujas relações ainda precisam ser melhor compreendidas.

De natureza complexa, o arcabouço geológico do Quadrilátero Ferrífero é constituído por quatro grandes unidades litoestratigráficas principais: complexos granito-gnáissicos metamórficos, que formam o embasamento cristalino, sotoposto à sequência arqueana de rochas metavulcano-sedimentares do Supergrupo Rio das Velhas e, sobre eles, dois espessos pacotes de rochas metassedimentares proterozoicas: o Grupo Itacolomi e o Supergrupo Minas. Esse é o conjunto litológico de maior significância regional, ao qual se devem as feições mais espetaculares do relevo, e a principal fonte de riqueza atual, o minério de ferro, (Figura $1 \mathrm{~A}$ ). Todo o conjunto é seccionado por diques máficos, intrudidos em eventos de deformação posteriores e, localmente, ocorrem bacias terciárias de dimensões restritas, algumas delas importantes jazidas de bauxita.

A região foi palco de eventos extensionais e compressionais superpostos, responsáveis pela formação de megaestruturas, como sinclinais, anticlinais e megafalhamentos (Figura $1 \mathrm{~A}$ ), que têm um papel destacado na evolução geomorfológica e na conformação do relevo atual. Essas amplas estruturas articuladas em sinclinais e anticlinais foram desmontadas pela erosão, desde o Cretáceo, que promoveu a inversão do relevo, com os anticlinais correspondendo atualmente aos vales dissecados e as sinclinais situadas em posição elevada, cujas abas, sustentadas por litologias especiais do Supergrupo Minas, constituem muitos dos alinhamentos serranos que caracterizam a região. Assim, o relevo regional apresenta uma grande diversidade de feições morfológicas, com contrastes bastante significativos. Todo o conjunto está sobrelevado, com intervalo de altitude entre 900 e 1.600 metros, que chega a 2.000 metros na serra do Caraça.

Em conexão com as variáveis geológicas e geomorfológicas, os solos apresentam padrões de ocorrência característicos nos ambientes que compõem o Quadrilátero Ferrífero como um todo, grande parte deles bem representados na área de estudo, em que foram identificados sete pedoambientes, assim denominados: Depressão do Paraopeba, Serras Itabiríticas, Platô da
Moeda, Vale do Rio das Velhas, Gandarela, Vale do Conceição e Serra do Caraça (Figura 1 B).

Entre os ambientes reconhecidos, apenas o das Serras Itabiríticas não constitui uma unidade inteiriça (Figura 1 B). A Depressão do Paraopeba, por outro lado, encontra-se fora dos limites estritos do Quadrilátero Ferrífero propriamente dito, em sua borda oeste, e apresenta feições fisiográficas representativas de grande parte dos terrenos granito-gnáissicos que o envolvem, com relevo de amplitude modesta, constituído por colinas convexas, em geral amplas, e espesso manto de alteração. Alguns elementos, todavia, a distinguem como área de transição, entre os quais a ocorrência de cerrado em topos mais elevados, entremeado à vegetação de floresta subperenifólia dominante. Predominam Latossolos Vermelhos, de textura argilosa e baixa fertilidade natural, em geral álicos (perfil P05; Tabela 1), às vezes com horizonte $\mathrm{B}$ pouco espesso, condição que proporciona a ocorrência de voçorocas, por exposição do horizonte $\mathrm{C}$ de natureza muito friável, que se estende a grandes profundidades (Resende et al., 2007). Em geral, ocorrem associados a Cambissolos, dominantes nas encostas de vale e fundos de grotas, e em alguns topos estreitos sob vegetação de cerrado ou campo cerrado (perfis P28 e P26), nos quais os teores de carbono orgânico são bem inferiores aos dos solos sob floresta. Em menor proporção, nas áreas de maior dissecamento e relevo mais acidentado, ao sul, ocorrem Argissolos Vermelhos (perfil P06) e Vermelho-Amarelos, sempre com vegetação nativa de floresta subperenifólia.

$\mathrm{O}$ contato com as serras adjacentes é marcado por encostas íngremes, com predomínio de Cambissolos e Neossolos Litólicos, sob vegetação de cerrado ou campo cerrado na base da escarpa da serra da Moeda, a leste, ou sob floresta na borda da serra dos Três Irmãos, ao norte, em cujo sopé distinguem-se formas pedimentares, de contornos já bastante reduzidos pela erosão, que apresentam Latossolos de intensa cor vermelha e elevada concentração de óxidos de ferro.

Distribuídas por todo o Quadrilátero nas imediações das serras, em rampas coluvionares, por vezes extensas (Barbosa, 1980), as formações pedimentares, às quais estão diretamente relacionados os Latossolos Vermelhos perférricos, típicos da região, completam a sequência topográfica das Serras Itabiríticas, cujos topos elevam-se entre 1.300 e 1.600 metros de altitude. Expostas por largos períodos aos processos 
erosivos, grande parte dessas serras se apresenta como alinhamentos de cristas aguçadas, sobre vertentes muito íngremes, com solos rasos (Neossolos Litólicos e Cambissolos) sob rala cobertura de gramíneas, e áreas menores sob floresta. Em alguns pontos, sobressaemse picos isolados constituídos por hematita compacta, cujo representante mais destacado é o Pico do Itabirito, na serra homônima, divisado a grandes distâncias na região.

Em decorrência do forte dobramento a que foram submetidas as espessas camadas metassedimentares que constituem o Supergrupo Minas, uma característica bem marcante dessas serras é o aspecto distinto das faces opostas de suas vertentes, o que é evidente nas abas dos sinclinais, como na Serra da Moeda. Enquanto no rebordo externo se divisa uma faixa com afloramentos de quartzito, ladeada por solos pouco espessos de cor clara, na face interna, os solos, igualmente rasos e em geral muito pedregosos, têm como material de origem o itabirito, e apresentam cor vermelho-escura muito intensa, em razão da extrema concentração de ferro. Nos solos amostrados na encosta da Serra da Moeda (Ex06, Ex15 e Ex19; Tabela 2), os teores de $\mathrm{Fe}_{2} \mathrm{O}_{3}$ obtidos pelo ataque sulfúrico encontram-se entre 532 e $839 \mathrm{~g} \mathrm{~kg}^{-1}$, sendo que o Ex06 também apresentou considerável concentração de óxidos de Mn. Mas o elemento mais marcante dessas serras, e que lhes dá um caráter único, talvez seja o extenso capeamento de canga - uma formação superficial constituída por fragmentos de rocha soldados em matriz ferruginosa -, que recobre grande parte dos topos arredondados com suave ondulação, mas que, às vezes, estende-se pela encosta interna, inclusive em declives acentuados. Sobre elas, um recobrimento de líquens e de uma flora subarbustiva esparsa dá-lhes uma feição muito característica, de fácil reconhecimento à distância. Em alguns trechos, esses topos apresentam maior amplitude, como na Serra da Água Limpa (Figura 1 B), onde, entremeadas à canga, em condição topográfica que sugere relação com antigas linhas de drenagem, manchas de floresta perenifólia recobrem solos muito vermelhos e profundos (perfil P02), constituídos por grande quantidade de concreções ferruginosas. Por isso, são atualmente classificados como Plintossolos Pétricos concrecionários (Santos et al., 2006), embora apresentem grau de desenvolvimento pedogenético muito avançado, evidenciado tanto por suas características químicas e mineralógicas (Carvalho

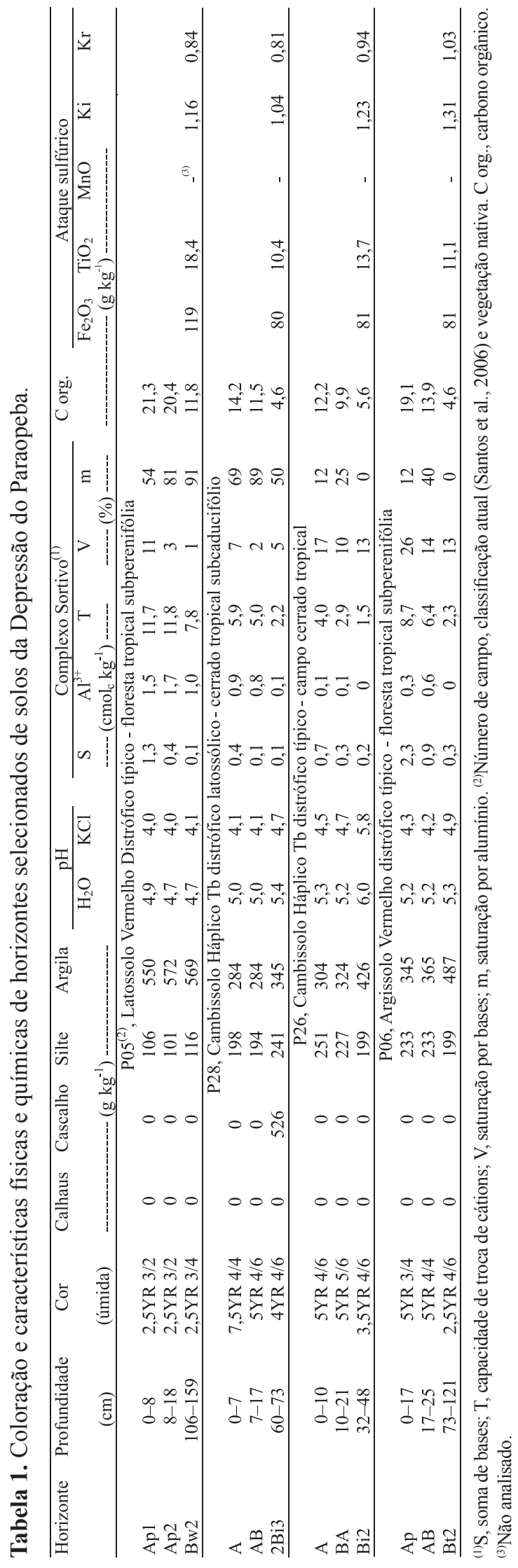


Filho, 2008), como pelo aspecto morfológico típico de horizonte B latossólico.

Dispersos em meio à canga, sob a qual ocorre material pedogenizado de cor vermelha, como indicado pela presença de cupinzeiros, encontram-se ainda pequenos aglomerados de vegetação arbustiva que se sustenta sobre estreita camada de material terroso acima da bancada laterítica, de cujas análises destaca-se a grande concentração de matéria orgânica no horizonte superficial (perfil Ex14). Merece destaque também a ocorrência, ainda menos comum, de pequenas áreas deprimidas de conformação subarredondada, no topo da Serra da Moeda, em que, mesmo na época seca, o lençol freático está próximo da superfície, mas que apesar disso, apresentam Latossolos Vermelhos perférricos, representados pelo perfil Ex20 (Tabela 2).

O Platô da Moeda, em estreita relação com a Serra da Moeda e a Serra do Itabirito que o ladeiam a oeste e a leste (Figura 1 B), respectivamente, e são responsáveis pela preservação de sua estrutura como núcleo de um amplo sinclinal geomorfologicamente suspenso, apresenta uma paisagem peculiar, algo simétrica. Contíguo àquelas, em cada um dos flancos leste e oeste, distingue-se uma faixa relativamente estreita de pequenas colinas, às quais se entremeiam formações pedimentares, cujos solos, sob vegetação nativa de campo cerrado ou mesmo campo, caracterizam-se pelos teores de ferro extremamente elevados, distintivos do caráter perférrico, e pela intensa cor vermelha, em alguns casos com tonalidade bastante escurecida.

A ocorrência de pedregosidade, referente a expressivo concrecionamento, é também muito comum, principalmente no relevo colinoso, cujos solos, em geral relacionados à Formação Gandarela, apresentam horizonte B incipiente (perfil P04; Tabela 3) ou, em menor proporção, B latossólico (perfil Ex08). Esses solos, pela introdução do conceito de horizonte concrecionário na atual versão do Sistema Brasileiro de Classificação de Solos (Santos et al., 2006), passaram a se enquadrar como Plintossolos Pétricos concrecionários. Solos semelhantes aos anteriores, mas com participação mais efetiva de materiais transportados, são também comuns nas rampas pedimentares conectadas às serras e com certa tendência a se localizar nas partes superiores dessas encostas suaves, às vezes como espessas massas soldadas por matriz ferruginosa.

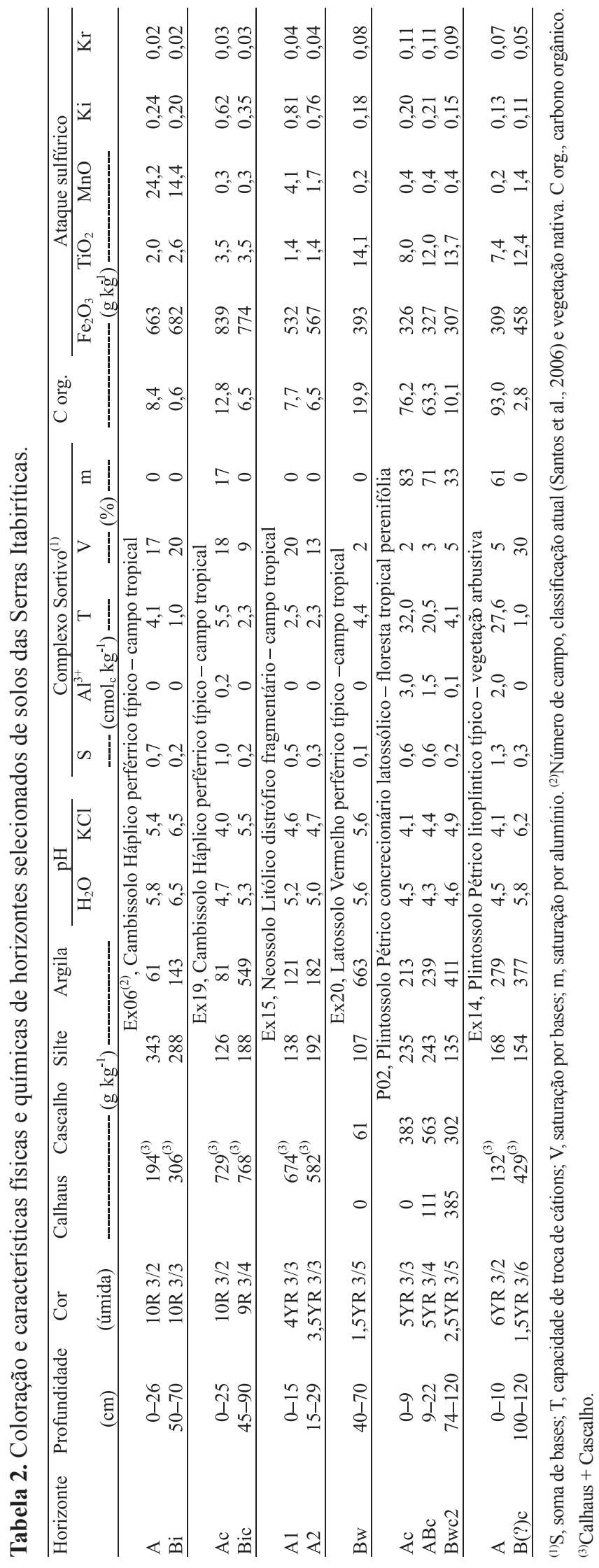


Nas áreas mais baixas, ou em relevo levemente deprimido, predominam Latossolos Vermelhos perférricos (perfil Ex04), em que a ocorrência de concreções se restringe aos horizontes inferiores, em geral de pequeno tamanho, tipo chumbo de caça.

$\mathrm{Na}$ zona central, de maior amplitude territorial, o relevo é formado por amplas colinas de conformação convexa, embora elevadas, com grande domínio de Cambissolos Háplicos, em geral cascalhentos, por vezes pedregosos, de cores bruno-amareladas, porém com teores de óxido de ferro relativamente altos, a exemplo do perfil P07 (Tabela 3); nas encostas íngremes dos vales que a dissecam, predominam Neossolos Litólicos, com horizonte A assente sobre a rocha ou sobre saprolito duro, em associação com Neossolos Regolíticos, alguns com exíguo horizonte $\mathrm{B}$ (perfil P08). A estes últimos, em geral relacionados a filitos e filitos dolomíticos do Grupo Piracicaba, está associada a ocorrência de voçorocas, em razão da grande friabilidade e profundidade do horizonte C. Ocorrem ainda alguns vales mais abertos, onde a transição para o encaixe das drenagens faz-se por rampas coluvionares, talvez contemporâneas dos pedimentos que orlam as serras marginais, às quais estão relacionados Latossolos de cores, em geral avermelhadas. Independentemente do tipo de solo, em toda essa área central é grande o domínio da vegetação campestre (campos limpos), com presença bem menor de floresta subperenifólia, em acentuado contraste, ao redor de algumas cabeceiras de drenagem ou bordejando os cursos d'água.

Na parte central da APA Sul, o Vale do Rio das Velhas constitui o ambiente de maior amplitude territorial em sua área (Figura 1 B), no qual se distinguem dois conjuntos principais. Um conjunto é contituído pela porção centro-ocidental, mais diretamente relacionada ao curso do próprio Rio das Velhas, de relevo acidentado, montanhoso e forte ondulado, com elevações íngremes entremeadas por vales estreitos, encaixados e profundos. O outro conjunto é constituído por uma faixa a leste, de aspecto bastante característico, dado pela alternância de alinhamentos rochosos, intercalados por patamares escalonados de topografia relativamente suave.

A área de forte dissecamento promovido pelo Rio das Velhas e seus afluentes apresenta um padrão de paisagem muito expressivo dentro do Quadrilátero Ferrífero. Caracteriza-se por uma sucessão de elevações

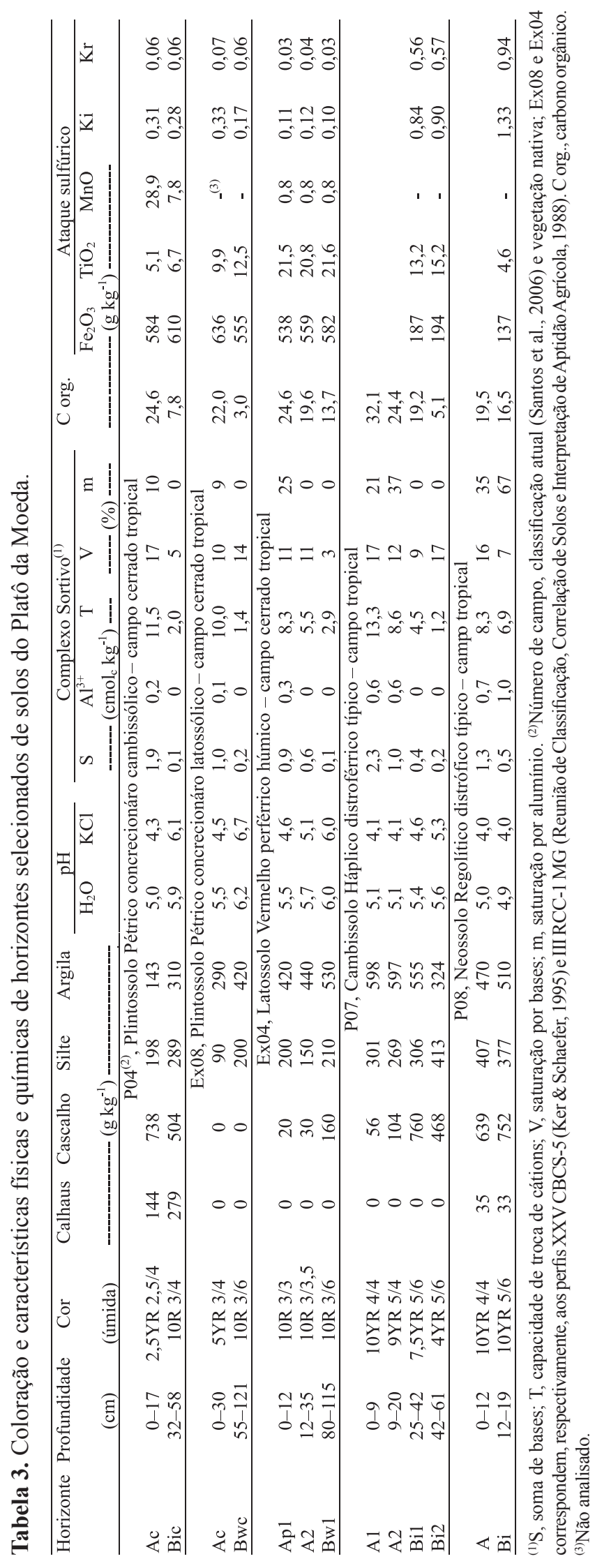


íngremes, bastante ravinadas, com topos estreitos, estendidos em ramificações divergentes, sob vegetação de campo cerrado, ou mesmo campo com árvores esparsas, em forte contraste coma floresta subperenifólia que avança ao longo dos vales. Independentemente da vegetação nativa, é grande o domínio de Cambissolos Háplicos, de fertilidade natural invariavelmente baixa. Nas áreas sob campo cerrado e campo, esses solos apresentam textura média ou argilosa, com teores de silte em geral superiores aos de argila, e ocorrência comum de cascalhos (perfis P03 e P23; Tabela 4). Além disso, nos trechos mais íngremes, apresentam pedregosidade superficial e horizonte B pouco espesso - que caracteriza solos lépticos ou líticos -, com frequência associados a Neossolos Litólicos (perfil P29). Pequena área, junto à Serra de Itabirito, distoa desse padrão, tanto pela conformação topográfica, um pouco mais suave, como pela presença de solos com características peculiares, representados por Latossolos e Cambissolos latossólicos de caráter perférrico, mas com cores em geral brunado-escuras (perfis P33 e Ex09), e ocorrência mais localizada, de Latossolos Vermelhos perférricos (perfil Ex02), relacionados às rochas máfico-ultramáficas (serpentinitos, metagabros e esteatitos) do Complexo Córrego dos Boiadeiros.

Nas áreas sob floresta, há maior variabilidade das características e dos tipos de solos. Também dominantes, os Cambissolos tendem a apresentar horizonte B um pouco mais espesso, com presença frequente de fragmentos de rocha em diferentes estádios de intemperização em meio ao material terroso, o que indica forte relação com material coluvionar, mas a característica mais destacada dos solos sob mata, em relação àqueles sob campo cerrado e campo, refere-se às maiores espessura e teor de matéria orgânica do horizonte A, além dos conteúdos mais elevados de alumínio trocável (perfil P30). Os trechos de maior encaixe das drenagens, de relevo muito íngreme (escarpado e montanhoso), apresentam Neossolos Litólicos e Cambissolos lépticos ou líticos, além de pequenos afloramentos de rocha. Menos frequentes, Argissolos Vermelhos e Vermelho-Amarelos tendem a ocorrer em nível topográfico inferior, com destaque para uma superfície mais baixa nos arredores da cidade de Rio Acima, de relevo forte ondulado e ondulado, distinto do padrão dominante na região, onde predominam Argissolos Vermelho-Amarelos cambissólicos (perfil $\mathrm{P} 12$ ). Entremeados às elevações dessa área, ocorrem pequenos terraços fluviais com Cambissolos Flúvicos e Argissolos Vermelho-Amarelos cambissólicos, ao lado de pequenas várzeas com Neossolos Flúvicos.

A transição para a paisagem a leste é bem destacada, marcada por encostas íngremes, com solos bastante rasos e, em geral, Neossolos Litólicos. Condicionada à grande resistência ao intemperismo e à estrutura dobrada com acentuado ângulo de mergulho dos metassedimentos do Grupo Maquiné (quartzitos micáceos, quartzitos sericíticos e metaconglomerados, com intercalações de xistos e filitos), essa porção oriental do Vale do Rio das Velhas é dominada por afloramentos de rocha, que se sobressaem em cristas alinhadas na direção sudeste-noroeste, intercaladas por vales de profundidade variável e trechos relativamente extensos de relevo suave (ondulado e suave ondulado), dispostos em patamares que se elevam progressivamente em direção à borda ocidental da Serra da Água Limpa. Mesmo nos trechos mais suaves, o horizonte B não chega a um metro de profundidade, e é comum ocorrerem pequenos aglomerados, com lajes rochosas à superfície. Predominam Cambissolos de textura média, com elevados teores de areia (perfis P11 e P35), além de Neossolos Litólicos, sob campo ou campo cerrado. A vegetação florestal restringe-se aos fundos de vale e pequenas grotas, sobre solos, em geral, também de pequena profundidade (perfil P14; Tabela 4), em que se sobressai a maior concentração de matéria orgânica, além de teores de alumínio trocável muito mais elevados do que os solos sob vegetação campestre.

Circunscrita por serras itabiríticas (Figura 1 B), a região do Gandarela corresponde a uma superfície dissecada, de relevo forte ondulado e montanhoso, sob densa cobertura florestal, ainda hoje bem preservada, que apresenta caráter perenifólio nas adjacências das serras que a envolvem. Apesar das inúmeras analogias com o Platô da Moeda, quanto à macroestruturação geomorfológica, e de apresentar a mesma sequência estratigráfica, essa região tem as características ambientais muito distintas. Sob condições de dissecamento bem mais intenso, o relevo apresenta-se bastante acidentado, com elevações de perfil côncavo e topos estreitos, entremeadas por vales encaixados, com ocorrência mais restrita de rampas coluvionares embutidas.

Condicionados à grande diferença na constituição das unidades litológicas, individualizam-se dois 


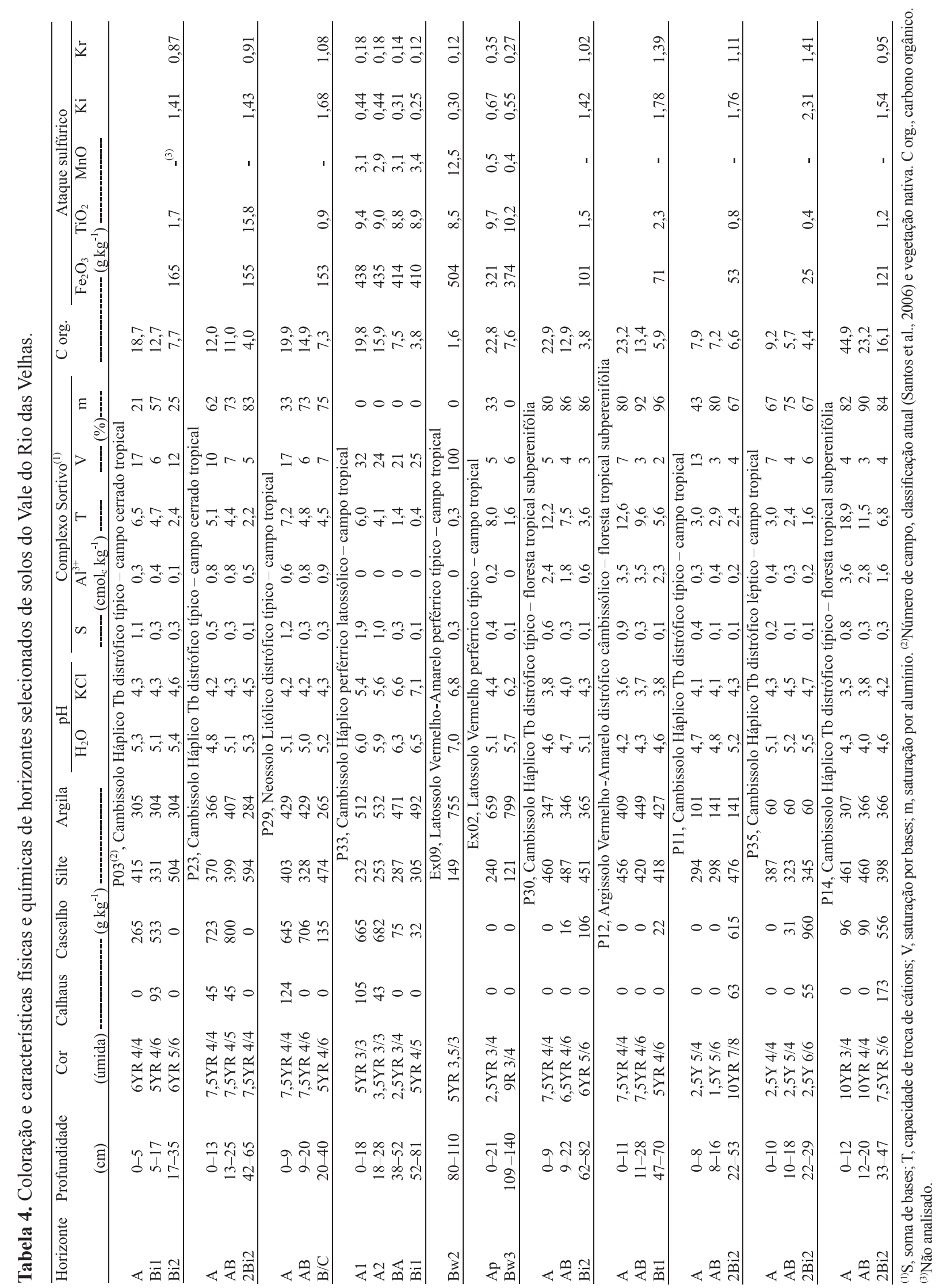


conjuntos pedológicos de características muito contrastantes, realçadas sobretudo pela coloração dos solos. De notável escurecimento, os solos relacionados aos dolomitos ferruginosos da Formação Gandarela, que ocorrem em faixa adjacente às serras, apresentam teores muito elevados de óxidos de ferro e de manganês, dos maiores já registrados no Brasil (Carvalho Filho, 2008) e no mundo (Kabata-Pendias \& Pendias, 2001; Dowding \& Fey, 2007), com extremos de $713 \mathrm{~g} \mathrm{~kg}^{-1}$ de $\mathrm{Fe}_{2} \mathrm{O}_{3}$ e 48,6 $\mathrm{g} \mathrm{kg}^{-1}$ de $\mathrm{MnO}$ pelo ataque sulfúrico (perfis P01, P25 e P37; Tabela 5). Há grande predomínio de Cambissolos Háplicos, de caráter perférrico, endopedregosos ou pedregosos, por vezes concrecionários (petroplínticos), com ocorrência menor de Latossolos Vermelhos perférricos. Por outro lado, os solos relacionados às rochas do Grupo Piracicaba, apresentam cor pálida, pelo que se infere que contêm baixos teores de óxidos de ferro (Kämpf \& Curi, 2000). Em geral, referen-se a Cambissolos Háplicos de textura média, com ocorrência menor, de preferência nas posições mais baixas da paisagem, de Latossolos Vermelho-Amarelos, ou ainda de Argissolos Vermelho-Amarelos, ambos com caráter intermediário para Cambissolos.

Comprimido entre a serra que limita o sinclinal Gandarela, a oeste, e o maciço do Caraça, a leste (Figura 1 B), o Vale do Conceição corresponde a um anticlinal invertido, todo escavado sobre litologias do Supergrupo Rio das Velhas, em que se distinguem duas unidades de paisagem. Nas cabeceiras, em um patamar elevado situado logo abaixo das escarpas quartzíticas do Caraça, subsiste uma superfície aplainada, constituída por colinas convexas de topos relativamente amplos, recobertos por vegetação campestre, que lembra, em muito, partes da paisagem do Platô da Moeda, inclusive em nível topográfico equivalente, entre 1.300 e $1.450 \mathrm{~m}$ de altitude, e dá a impressão de corresponderem à mesma superfície de erosão. Em toda essa área, predominam Cambissolos Háplicos, de textura média (perfil P17; Tabela 6) que, nos trechos de maior declividade dos vales que a dissecam, tendem a ser cascalhentos e pedregosos e a apresentar pequena profundidade (lépticos ou líticos), às vezes associados a Neossolos Litólicos. O prolongamento dessa superfície elevada é bem perceptível ao norte, porém em nível topográfico um pouco mais baixo, com relevo forte ondulado e ondulado, sob vegetação de floresta subperenifólia, que recobre Latossolos Vermelho-Amarelos de textura

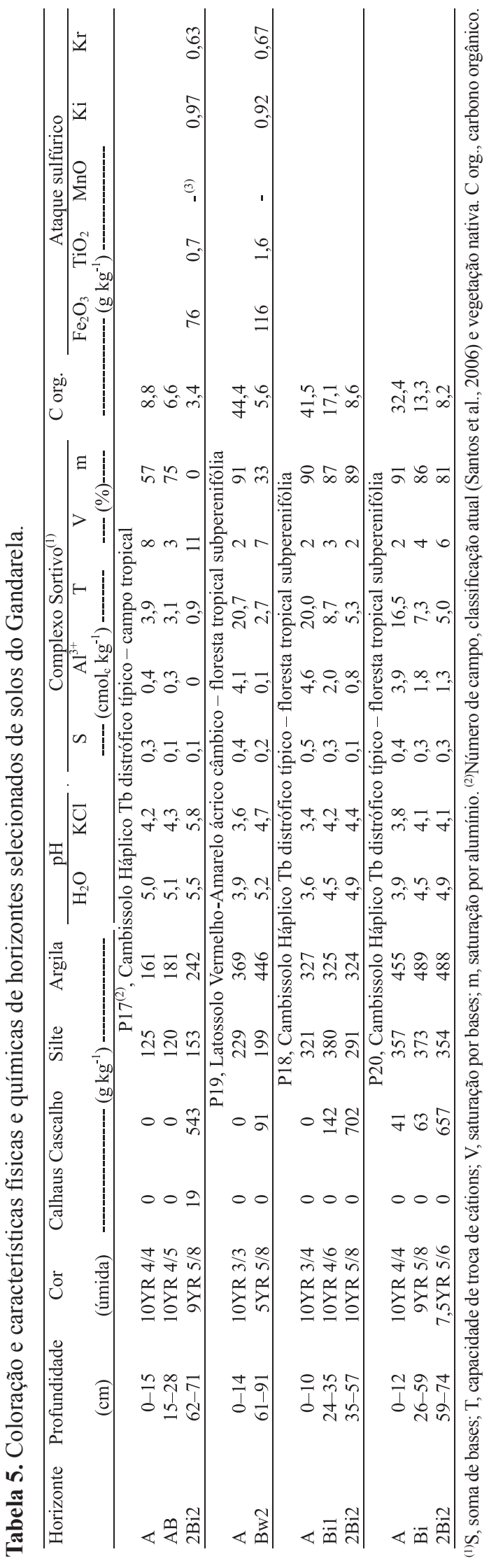


argilosa e caráter ácrico (perfil P19; Tabela 6), em geral com características intermediárias para Cambissolos, com os quais encontram-se associados. Aí ocorrem também pequenas várzeas, com Gleissolos Háplicos ou Melânicos, sob campo higrófilo.

O limite dessa superfície mais elevada é bastante acentuado, marcado pela presença de altas cachoeiras, com solos bastante rasos (Neossolos Litólicos) e, não raro, exposições rochosas ou vales muito íngremes sob densa cobertura florestal, em que predominam Cambissolos, em geral com solum pouco espesso (perfis P18 e P20; Tabela 6). Merecem destaque, nos solos sob floresta dessa área, os altos teores de alumínio trocável, principalmente nos horizontes mais superficiais, em conjunto com elevado conteúdo de carbono orgânico. Esses solos contrastam-se com os solos sob vegetação campestre, em que as concentrações daquele cátion ácido no complexo de troca são inferiores ao limite definido para distinção do caráter álico $\left(0,5 \mathrm{cmol}_{\mathrm{c}} \mathrm{kg}^{-1}\right)$.

Logo abaixo das cabeceiras do vale, o Rio Conceição é ladeado por uma sucessão de elevações de cumes estreitos, cujo padrão de distribuição de solos é mais representativo da porção leste do Quadrilátero Ferrífero, dissecada pelos afluentes do Rio Doce, em que se destaca a exuberância da Mata Atlântica. De relevo montanhoso e forte ondulado, predominam nessa área Cambissolos, sobretudo nas encostas côncavas e trechos mais íngremes, com ocorrência menor de Latossolos Vermelho-Amarelos, ambos de textura argilosa, em topos um pouco mais amplos e encostas de conformação convexa. Mais a jusante, o Rio Conceição é ladeado por pequenos terraços e encostas onduladas ou forte onduladas, ocupadas por Latossolos Vermelhos, com maior expressão na proximidade da confluência com o Rio Caraça, limite nordeste da APA Sul, que tem um depósito aluvial mais expressivo, onde predominam Neossolos Flúvicos.

$\mathrm{Na}$ extremidade oriental da área, encontra-se a Serra do Caraça, cujo ponto culminante ultrapassa $2.000 \mathrm{~m}$ de altitude. Forma um conjunto serrano de grandes dimensões, com vales intermontanos embutidos. A maior parte de sua área é representada por exposições rochosas (quartzitos), com intercalações de solos muito rasos (Neossolos Litólicos) sob campo rupestre, num arranjo de serras com cristas em altitudes variadas.

A conexão com a superfície embutida no interior desse conjunto é feita por encostas íngremes, por vezes escalonadas, em que os blocos de quartzito

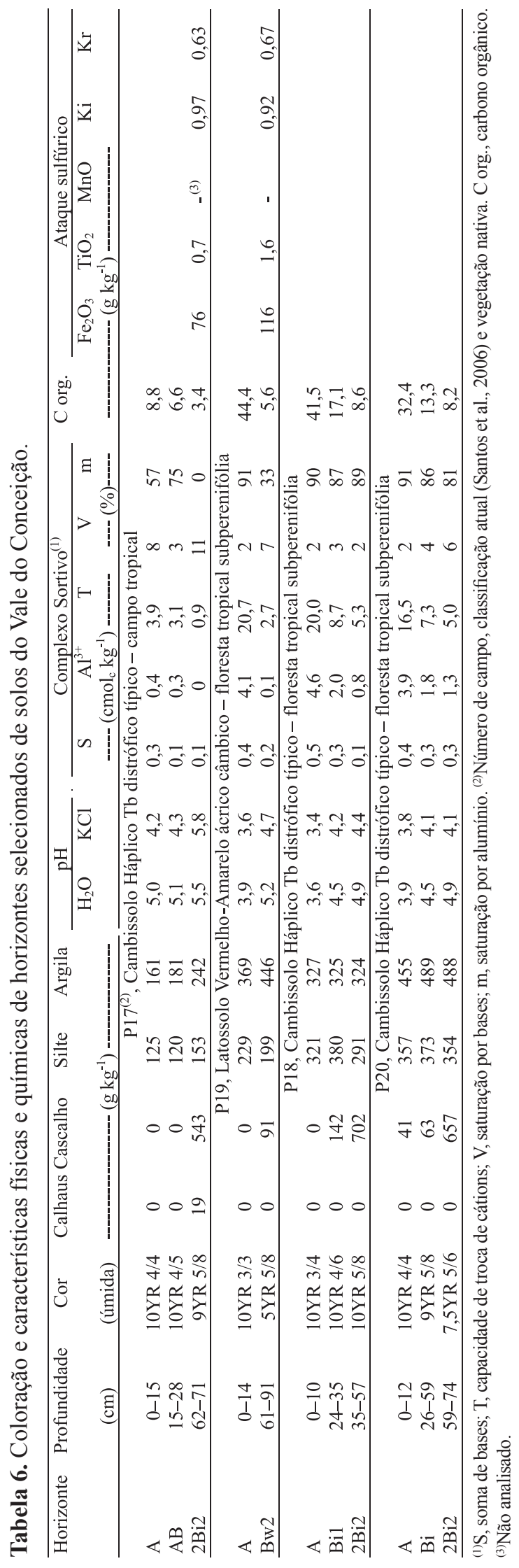

Pesq. agropec. bras., Brasília, v.45, n.8, p.903-916, ago. 2010 
predominam, e por bordas escarpadas, com grandes desnivelamentos topográficos, marcam os limites com as paisagens adjacentes. No contato com as cabeceiras do Rio Conceição, essas bordas são recobertas por vegetação campestre, sobre Neossolos Litólicos entre grande número de blocos de rocha, enquanto em toda a face norte é a floresta subperenifólia que coloniza os espaços entre as lajes de quartzito. A tensão entre formações florestais e campestres reproduz-se também internamente, com a mata recobrindo, nitidamente, as estreitas linhas de falha geológica, relacionadas a rochas básicas intrusivas, cuja intemperização deu origem a Cambissolos Háplicos, em geral de textura argilosa, e em faixas estreitas ao longo dos cursos d'água ou sobre algumas encostas adjacentes a eles. No vale intramontano, de relevo relativamente suave, com pelo menos dois níveis topográficos, predomina, no entanto, uma vegetação de campo tropical ou uma flora arbustiva esparsa constituída quase exclusivamente por candeias (Eremanthus erythropappus), que recobrem Cambissolos Háplicos, de cores bastante pálidas e com teores de argila e matéria orgânica muito baixos (perfil P31; Tabela 7).

Numa avaliação global, excluída a Depressão do Paraopeba, que se insere no âmbito das pedopaisagens que envolvem o Quadrilátero Ferrífero, sobressaise na área em estudo o grande domínio de solos pouco evoluídos, com forte influência do material de origem em suas características. Infere-se, portanto, uma preponderância geral dos processos erosivos sobre a pedogênese, condicionada tanto pelo relevo, em geral acidentado, como pela forte resistência ao intemperismo da maior parte das rochas regionais ou, ainda, pelo baixo recobrimento vegetal nas áreas sob campo cerrado e campo, refletida na predominância de Cambissolos e Neossolos Litólicos, além da presença de afloramentos rochosos em extensões consideráveis. A ocorrência desses solos é expressiva mesmo em terrenos mais conservados, de relevo suave, situados em nível topográfico elevado, como no Platô da Moeda e em alguns trechos do Vale do Rio das Velhas, sobretudo na sua porção oriental, e também nas cabeceiras do Rio Conceição, assim como nos níveis internos do Caraça, onde predominam Cambissolos sob vegetação campestre. Nessa superfície elevada, a presença de Latossolos é bastante restrita, verificada apenas em áreas confinadas, ao que parece preenchendo depressões de um relevo pretérito, ou relacionados a rampas coluvionares, em particular aos pedimentos adjacentes

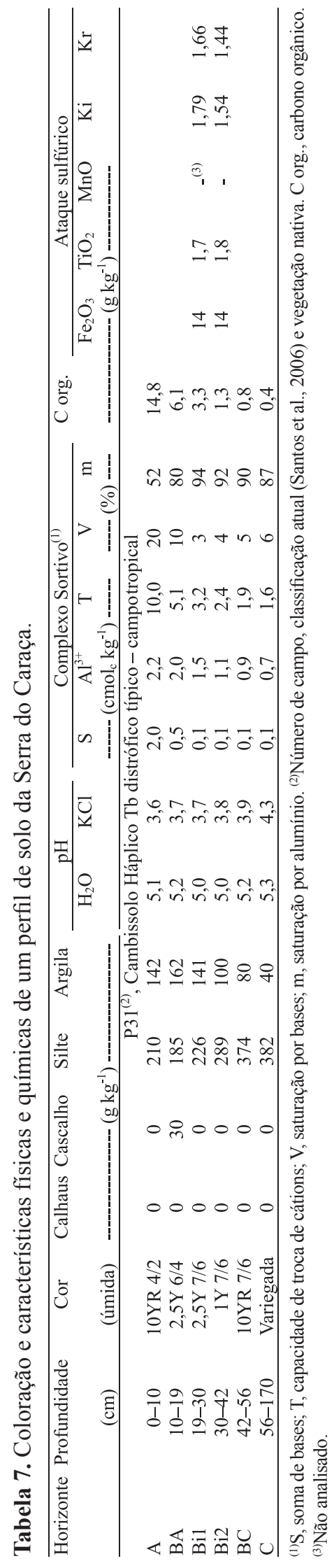


às serras itabiríticas, que se caracterizam como paisagem típica de ocorrência dos Latossolos Vermelhos perférricos na região. De um modo geral, no entanto, os Latossolos tendem a ocorrer nas encostas íngremes, em relevo montanhoso e forte ondulado, preferencialmente de conformação convexa, dos vales sob floresta, onde se verifica ainda a presença de Argissolos, em especial nos trechos mais rebaixados, de maior dissecamento.

Apesar do forte contraste entre as formações vegetais que ocorrem na região, cuja transição é invariavelmente bem marcada, não se observa qualquer relação mais direta entre elas e as classes ou características dos solos, quer seja a profundidade efetiva ou mesmo a disponibilidade de nutrientes. A deficiência em bases trocáveis é generalizada, embora com tendência geral, excluídos os solos ferruginosos, de os teores de Al trocável serem bem mais elevados nos solos sob floresta, ao que parece relacionados aos maiores conteúdos de matéria orgânica. Assim, em vista da posição que ocupa na paisagem, a presença da vegetação florestal parece relacionada à maior disponibilidade de água (Spera et al., 1996), ao mesmo tempo em que sugere seu avanço progressivo, em substituição às formações campestres.

Parece também evidente a influência do tipo de cobertura vegetal sobre o conteúdo de matéria orgânica dos solos da área, com exceção de alguns solos com expressiva participação de compostos ferruginosos em sua constituição, o que lhes imprime características peculiares e os distingue como conjunto à parte, de ocorrência pouco comum na paisagem brasileira. Estão relacionados a três materiais de origem principais: itabiritos da Formação Cauê, dolomitos ferruginosos da Formação Gandarela e rochas básico-ultrabásicas do Complexo Córrego dos Boiadeiros, os últimos de ocorrência restrita. Alguns deles, em especial os solos relacionados à formação Gandarela, destacamse pelas cores muito escuras, quase pretas, e ocorrência expressiva de compostos de manganês, características que talvez mereçam ser contempladas pelo Sistema Brasileiro de Classificação de Solos em nível taxonômico mais elevado. Outra característica marcante desse conjunto de solos é dada pela presença comum de grande quantidade de concreções ferruginosas (petroplintita) na fração grosseira (calhaus e cascalhos), o que tem levado à classificação de grande parte deles como Plintossolos Pétricos, a despeito das condições pedogenéticas muito distintas em relação ao ambiente de formação de plintita, a par de outras características morfológicas diferenciais. Assim, em razão da incongruência com o caráter morfogenético considerado como princípio básico da classificação brasileira de solos, é questionada a figura do horizonte concrecionário como horizonte diagnóstico, conforme definido pelo sistema de classificação de solos em vigor (Santos et al., 2006), e é sugerida a necessidade de reavaliação desse critério de distinção taxonômica, assim como da pertinência do próprio enquadramento de tais solos na classe em questão.

Do processo de concrecionamento resulta também um dos aspectos fisiográficos mais característicos do Quadrilátero Ferrífero, que é o extenso capeamento de cangas ferruginosas sobre os topos das serras, com destacada importância na sua evolução geomorfológica atual e pretérita. Por sua resistência à erosão, ao mesmo tempo em que constitui um dos principais fatores a retardar a ampliação dos vales ao longo do tempo geológico, e a contribuir para a preservação das estruturas antigas, em razão do contraste com o material subjacente, de natureza bem mais friável, esse capeamento é responsável pela elaboração de feições escarpadas muito íngremes nas bordas de algumas serras.

\section{Conclusões}

1. É marcante a influência do material de origem nas características dos solos da área em estudo, em que predominam solos pouco evoluídos (Cambissolos e Neossolos Litólicos), e em que se destaca o conjunto de solos de constituição ferruginosa, em geral de caráter perférrico, relacionados a três materiais de origem principais: itabiritos, dolomitos ferruginosos e rochas básico-ultrabásicas. Em geral, os solos relacionados aos dolomitos ferruginosos, da Formação Gandarela, apresentam também conteúdos muito elevados de óxidos de manganês, aos quais estão associadas cores muito escurecidas.

2. A ocorrência de Latossolos Vermelhos perférricos desprovidos de pedregosidade está relacionada, principalmente, às formações pedimentares nas adjacências das serras itabiríticas.

3. Em toda a área, com exceção dos solos ferruginosos, os teores de alumínio trocável, assim como os de matéria orgânica, são bem maiores nos solos sob floresta do que naqueles sob vegetação de campo cerrado ou campo, o que ao lado da condição topográfica sugere que a presença da floresta está relacionada a maior disponibilidade de água. 


\section{Referências}

BARBOSA, G.V. Superfícies de erosão no Quadrilátero Ferrífero, Minas Gerais. Revista Brasileira de Geociências, v.10, p.89-101, 1980.

CARVALHO FILHO, A. de. Solos e ambientes do Quadrilátero Ferrífero (MG) e aptidão silvicultural dos Tabuleiros Costeiros. 2008. 245p. Tese (Doutorado) - Universidade Federal de Lavras, Lavras.

CHEMALE JUNIOR, F.; ROSIÈRE, C.A.; ENDO, I. Evolução tectônica do Quadrilátero Ferrífero, Minas Gerais: um modelo. Pesquisas, v.18, p.104-127, 1991.

CLAESSEN, M.E.C. (Org.). Manual de métodos de análise de solo. 2.ed. rev. atual. Rio de Janeiro: Embrapa-CNPS, 1997. 212p. (Embrapa-CNPS. Documentos, 1).

COSTA, S.A.D. Caracterização de solos desenvolvidos de itabirito no Quadrilátero Ferríferro, MG. 2003. 71p. Dissertação (Mestrado) - Universidade Federal de Viçosa, Viçosa.

CURI, N.; FRANZMEIER, D.P. Effect of parent rocks on chemical and mineralogical properties of some Oxisols in Brazil. Soil Science Society of American Journal, v.51, p.153-158, 1987.

DORR II, J.V.N. Physiographic, stratigraphic and structural development of the Quadrilátero Ferrífero, Minas Gerais, Brazil. Washington: U.S. Geological Survey, 1969. 110p. (Geological Survey professional paper, 641-A).

DOWDING, C.E.; FEY, M.V. Morphological, chemical and mineralogical properties of some manganese-rich Oxisols derived from dolomite in Mpumalanga province, South Africa. Geoderma, v.141, p.23-33, 2007

FIGUEIREDO, M. do A.; FABRIS, J.D.; VARAJÃO, A.F.D.C.; COUCEIRO, P.R. da C.; LOUTFI, I.S.; AZEVEDO, I. de S.; GARG, V.K. Óxidos de ferro de solos formados sobre gnaisse do Complexo Bação, Quadrilátero Ferrífero, Minas Gerais. Pesquisa Agropecuária Brasileira, v.41, p.313-321, 2006.

KABATA-PENDIAS, A.; PENDIAS, H. Trace elements in soils and plants. $3^{\text {rd }}$ ed. Boca Raton: CRC, 2001. 413p.

KÄMPF, N.; CURI, N. Óxidos de ferro: indicadores de ambientes pedogênicos e geoquímicos. In: NOVAIS, R.F. de; ALVAREZ
V.H.; SCHAEFER, C.E.G.R. (Ed.). Tópicos em ciência do solo. Viçosa: Sociedade Brasileira de Ciência do Solo, 2000. v.1, p.107-138.

KER, J.C.; SCHAEFER, C.E.G.R. Roteiro da excursão pedológica Viçosa - Sete Lagoas, do Congresso Brasileiro de Ciência de Solos, Viçosa, Universidade Federal de Viçosa, Sociedade Brasileira de Ciência do Solo. Viçosa: UFV, 1995. $47 \mathrm{p}$.

RESENDE, M.; CURI, N.; REZENDE, S.B.; CORRÊA, G.F. Pedologia: base para distinção de ambientes. 5.ed. rev. Lavras: UFLA, 2007. 322p.

REUNIÃO DE CLASSIFICAÇÃO, CORRELAÇÃO DE SOLOS E INTERPRETAÇÃO DE APTIDÃO AGRÍCOLA, 3., 1988, Rio de Janeiro. Anais. Rio de Janeiro: Embrapa-SNLCS, 1988. 425p. (Embrapa-SNLCS. Documentos, 12).

SANTOS, H.G. dos; JACOMINE, P.K.T.; ANJOS, L.H.C. dos; OLIVEIRA, V.A. de; OLIVEIRA, J.B. de; COELHO, M.R.; LUMBRERAS, J.F.; CUNHA, T.J.F. (Ed.). Sistema brasileiro de classificação de solos. 2.ed. Rio de Janeiro: Embrapa Solos, 2006. $306 \mathrm{p}$.

SANTOS, R.D. dos; LEMOS, R.C. de; SANTOS, H.G. dos; KER, J.C.; ANJOS, L.H.C. Manual de descrição e coleta de solo no campo. 5.ed. rev. ampl. Viçosa: Sociedade Brasileira de Ciência do Solo; Rio de Janeiro: Embrapa-CNPS, 2005. 92p.

SHINZATO, E.; CARVALHO FILHO, A. de. Pedologia. In: PROJETO APA sul RMBH: estudos do meio físico. Belo Horizonte: Compania de Pesquisa de Recursos Minerais, 2005. v.5, pt.A-B, 53p. (Série programa informações básicas para a gestão territorial - GATE, 5)

SPERA, S.T.; FERREIRA, M.M.; CURI, N. Inter-relações entre propriedades físico-hídricas do solo e a ocorrência de vegetação de mata e campo adjacentes no Alto Rio Grande (MG). Ciência e Agrotecnologia, v.20, p.178-182, 1996.

VARAJÃO, C.A.C.; SALGADO, A.A.R.; VARAJÃO, A.F.D.C.; BRAUCHER, R.; COLIN, F.; NALINI JUNIOR, H.A. Estudo da evolução da paisagem do Quadrilátero Ferrífero (Minas Gerais, Brasil) por meio da mensuração das taxas de erosão $\left({ }^{10} \mathrm{Be}\right)$ e da pedogênese. Revista Brasileira de Ciência do Solo, v.33, p.1409-1425, 2009.

Recebido em 26 de janeiro de 2009 e aprovado em 3 de junho de 2010 